\title{
Feeding and Defaecation Patterns in Triatoma sordida
}

\author{
LB Crocco, SS Catalá*
}

\author{
Centro de Investigaciones Entomológicas de Córdoba *Cátedra de Biología Celular, FCEFN-UNC Velez \\ Sarsfield 299, 5000 Córdoba, Argentina
}

Triatoma sordida is a peridomestic Triatominae that could play an important role in the transmission of Trypanosoma cruzi, although its vectorial competence is not well known. The aim of this work was to evaluate two aspects of the vectorial competence: the feeding behaviour and defaecation patterns, and to compare them with $\mathrm{T}$. infestans. The feeding and defaecation patterns were studied in adults and fifth instar nymphs of $\mathrm{T}$. sordida fed ad libitum on a restrained pigeon. The results showed how the blood meal size controls excretion behaviour. Blood intake and time to first defaecation showed a significant negative correlation. Adults and nymphs frequently defaecated during the blood meal, reaching the maximum frequency within the first 10 minutes.

Key words: Triatoma sordida - feeding - defaecation - peridomestic

Among peridomiciliary vector species of Chagas disease, Triatoma sordida is showing increasing importance as a potential vector. In Brasil, $T$. sordida has been found invading houses from which $T$. infestans had been eliminated by insecticide spraying (Freitas et al.1960, Forattini et al.1982, 1983, 1984). Nymphal instars of $T$. sordida have been found in human dwellings in Argentina (in the provinces of Corrientes, Chaco and Santa $\mathrm{Fe}$ ), indicating domiciliary colonization behaviour (Carcavallo et al.1988).

These observations allow us to presume that $T$. sordida could play an important role in the transmission of Trypanosoma cruzi to man. However, there is no knowledge about how competent $T$. sordida is in the transmission of this parasite. Vectorial competence was defined by WHO (1983) as the species physiological ability to develop and to transmit a pathogenic agent. In Triatominae, the feeding habits and defaecation patterns are important among these abilities and differences between species may indicate differences in competence in disease transmission.

In order to understand better the efficiency of T. sordida in T. cruzi transmission, the aim of this work was to evaluate the feeding and defaecation characteristics and to compare them with $T$. infestans, the primary vector of Chagas disease in Argentina and other countries of the Latin American southern cone.

This work was supported by CONICOR and CONICET (Argentina).

Received 2 May 1995

Accepted 4 March 1996

\section{MATERIALS AND METHODS}

This work was carried out with adults and fifth instar nymphs of $T$. sordida, provided by the Servicio Nacional de Chagas (Argentina). The insects were maintained in the laboratory at $27 \pm$ $1^{\circ} \mathrm{C}$ and $60-70 \%$ humidity.

The insects were starved for 15 days after moulting and marked with acryllic paint on their thorax and/or tergites. After fasting, they were fed on a restrained pigeon. Each insect was observed continuously during feeding and for 10 min afterwards. For each feeding the following variables were obtained:

Blood meal size: as females and nymphs generally defaecate during feeding or within $10 \mathrm{~min}$ after feeding, the weight of the excreted faeces was included in the calculation of blood meal size (BMS):

$\mathrm{BMS}=(\mathrm{AF}-\mathrm{BF})+\mathrm{Wf}$ where,

$\mathrm{AF}$ : insect weight (mg) $10 \mathrm{~min}$ after feeding

$\mathrm{BF}$ : insect weight $(\mathrm{mg})$ before feeding

Wf: faeces weight (mg) excreted during feeding or within $10 \mathrm{~min}$ after feeding. The faeces were collected with microhaematocrit capillaries. These tubes were weighed without faeces and with the faeces to calculate the faeces weight. All the weights were measured using a Mettler balance with a precision of $0.01 \mathrm{mg}$.

Attack time: time (in seconds) since the insect was placed on the host until it began to feed was timed with a stopwatch.

Feeding time: was the time (in minutes) since the rostrum of the insect contacted the host skin until it detached the rostrum. This time represents the minimum contact time between vector and host.

Number and volume of defaecations emitted by the insect during feeding and within 10 min after 
feeding: the number of defaecations was registered by direct observation. In order to obtain the volume of the defaecations the microhaematocrit capillaries were previously calibrated in $\mu \mathrm{l}$. Immediately after feeding each insect was transferred to a Defaecation Frequency Recorder (DFR) (Zarate et al. 1984 , modified to allow $24 \mathrm{hr}$ registration), that permitted recording of the defaecations emitted in the $24 \mathrm{hr}$ after feeding (Fig. 1).

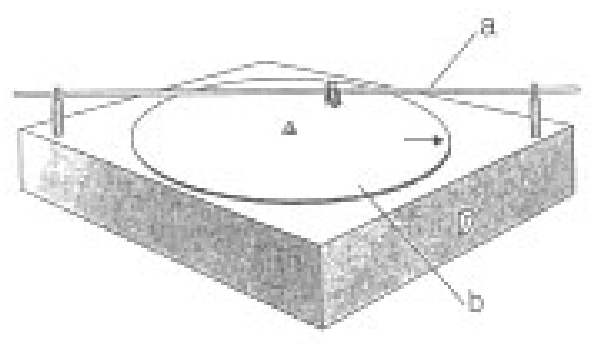

$5.6 \mathrm{~cm}$

Fig.1: defaecation frequency recorder. a: stationary bar for positioning bugs; $b$ : the platform is covered with filter paper and rotates once every $24 \mathrm{hr}$ to collect faecal spots.

In order to compare the excretion data with those obtained for $T$. infestans by other authors, the Defaecation Index of Zeledon et al. (1977) was used:

$$
\mathrm{DI}=\frac{\mathrm{A} \times \mathrm{B}}{100}
$$

where

A: percentage of insects that defaecated within 10 min after feeding

$B$ : average number of defaecations by the insect emitted within 10 min after feeding.

To compare the meal size between nymphs and adults of $T$. sordida with those of other species having different body sizes, a relative meal size index (RMS, relating meal size with insect weight before feeding) was obtained

$$
\mathrm{RMS}=\frac{\text { meal size }(\mathrm{mg})}{\text { insect weight }(\mathrm{mg})}
$$

The results obtained for feeding habits were compared with data obtained for T. infestans by other authors.

The Student t-test was used for comparison between means, and correlation between variables was carried out by standard liner regression.

\section{RESULTS}

Feeding patterns - Both nymph and adult $T$. sordida attacked the host soon after exposure, the females being the fastest (Table I). No significant relationship was found between attack time and insect weight before feeding either for nymphs or adults.

The BMS and the RMS were significantly higher in the fifth instar nymphs, which required more time to become completely engorged than adults. Females ingested significantly more blood than the males. Regression of BMS on insect weight before feeding showed significant negative correlation for females and males ( $F F r=-0.43, n=40$, $\mathrm{p}<0.0001 ; \mathrm{MM} \mathrm{r}=-0.32, \mathrm{n}=51, \mathrm{P}<0.0001$ ) (Fig. 2 ). No significant relationship was found between these variables for nymphs $(\mathrm{n}=66, \mathrm{r}=-0.05$ ).

Defaecation patterns - The highest proportion of defaecations from the first $24 \mathrm{hr}$ after feeding was emitted during the first $10 \mathrm{~min}$ (Fig. 3). Females and nymphs showed the highest percentages of insects defaecating while they were taking blood (Fig. 4). During the first 10 min after feeding the females defaecated more frequently and emitted urine drops much faster than males and nymphs (Table II). The volume of faeces emitted one hour after feeding, was significantly lower for males $(4.0 \pm 1.9 \mu \mathrm{l})$ than for females or nymphs $(8.7 \pm 7.7$ and $7.9 \pm 7.0 \mu$ respectively).

Blood meal size influenced the dejection emission time. Females that ingested $46.2 \mathrm{mg}$ or less and males and nymphs whose blood meals were equal to, or lower than 39.2 and $36.7 \mathrm{mg}$ respec-

TABLE I

\begin{tabular}{|c|c|c|c|c|c|c|c|c|c|}
\hline \multirow[t]{2}{*}{ Instar } & \multirow[t]{2}{*}{$\mathrm{n}$} & \multicolumn{2}{|c|}{$\begin{array}{l}\text { Attack time } \\
\quad(\min )\end{array}$} & \multicolumn{2}{|c|}{$\begin{array}{l}\text { Feeding time } \\
\text { (min) }\end{array}$} & \multicolumn{2}{|c|}{$\begin{array}{l}\text { Blood meal } \\
(\mathrm{mg})\end{array}$} & \multicolumn{2}{|c|}{$\mathrm{RMS}^{a}$} \\
\hline & & $\overline{\mathrm{x}}$ & $\mathrm{SD}$ & $\overline{\mathrm{x}}$ & SD & $\overline{\mathrm{x}}$ & SD & $\overline{\mathrm{x}}$ & $\mathrm{SD}$ \\
\hline Females & 49 & $1,6^{b}$ & 2,5 & $18,9^{d}$ & 10,6 & $91,1^{d}$ & 41,1 & $1,3^{d}$ & 0,8 \\
\hline Males & 59 & $2,9^{b}$ & 2,5 & $22,5^{d}$ & 12,1 & $46,8^{d}$ & 17,2 & $0,9^{d}$ & 0,6 \\
\hline Nymphs & 61 & $2,0^{c}$ & 3,1 & $33,7^{d}$ & 15,6 & $121,2^{d}$ & 73,0 & $4,1^{d}$ & 2,6 \\
\hline
\end{tabular}

Feeding pattern of adults and fifth instar nymphs of Triatoma sordida

$a$ : RMS relative meal size; $b$ : females differ significantly from males $(\mathrm{p}<0,001) ; c$ : nymphs differ significantly from females and males $(\mathrm{p}<0,0001) ; d$ : significant differences between females and males and nymphs $(\mathrm{p}<0,0001) ; \overline{\mathrm{x}}$ : mean; SD: standard deviation. 
TABLE II

Defaecation pattern of fifth instar nymphs and adults of Triatoma sordida

\begin{tabular}{|c|c|c|c|c|c|c|c|c|}
\hline \multirow[t]{3}{*}{ Instar } & \multirow{2}{*}{\multicolumn{2}{|c|}{$\begin{array}{l}\text { Time first defaecation } \\
(\mathrm{min})\end{array}$}} & \multicolumn{6}{|c|}{ Defaecations per insect } \\
\hline & & & & & & & & \\
\hline & $\bar{x}$ & SD & $\bar{x}$ & SD & $\overline{\mathrm{x}}$ & SD & $\bar{x}$ & SD \\
\hline \multirow[t]{2}{*}{ Females } & $1,0^{a}$ & 4,0 & $2,2^{a}$ & 1,6 & $2,9^{b}$ & 1,7 & 4,9 & 2,6 \\
\hline & \multicolumn{2}{|c|}{$\mathrm{n}=49$} & \multicolumn{2}{|c|}{$\mathrm{n}=15$} & \multicolumn{2}{|c|}{$\mathrm{n}=16$} & \multicolumn{2}{|c|}{$\mathrm{n}=15$} \\
\hline Males & \multicolumn{2}{|c|}{$\mathrm{n}=59$} & \multicolumn{2}{|c|}{$n=25$} & 1,5 & 0,5 & 2,0 & 1,1 \\
\hline Nymphs & 6,1 & 10,2 & 1,2 & 0,8 & $2,3^{b}$ & 1,7 & \multicolumn{2}{|c|}{$n=21$} \\
\hline
\end{tabular}

$a=$ females differ significantly from nymphs and males $(\mathrm{p}<0,0001) ; b=$ females and nymphs differ significantly from males $(\mathrm{p}<0,0001) ; c=$ males differ significantly from females and nymphs $(\mathrm{p}<0,0001)$; $d=$ nymphs differ significantly from females and males $(\mathrm{p}<0,0001) ; \bar{x}=$ mean $\cdot S n=$ standard deviation $\cdot n=$ numher of incerts

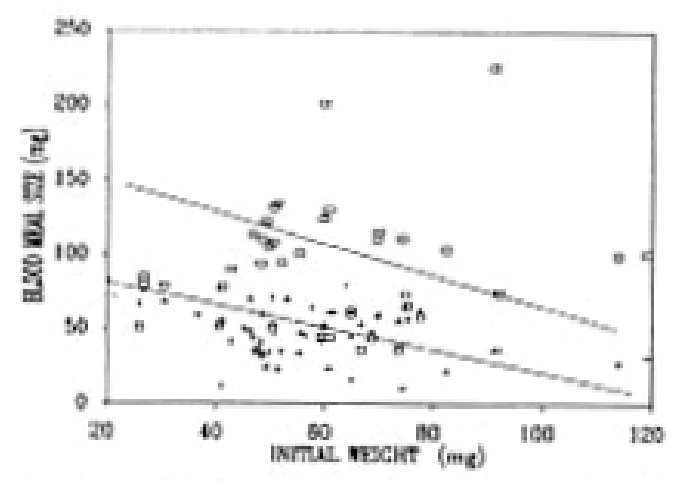

Fig. 2: relationship between insect weight before feeding $(\mathrm{mg})$ and blood meal size $(\mathrm{mg})$ in females and males of Triatoma sordida. $(\square)$ females $\mathrm{y}=139.48+0.59 \mathrm{x} ;(+)$ males $\mathrm{y}=64.15$ $+0.30 \mathrm{x}$

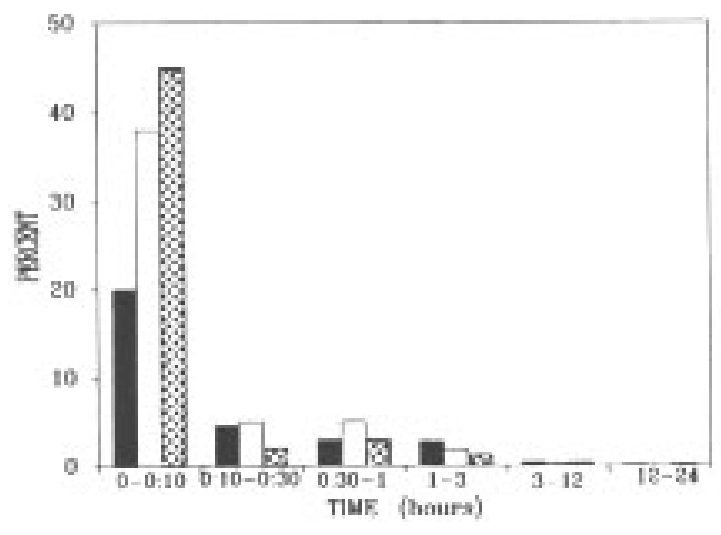

Fig. 3: percentage of defaecations emitted in $10 \mathrm{~min}$ within each time period by fifth instar nymph (ם), females $(\square)$ and males $(\square)$ of Triatoma sordida.

tively did not defaecate. For the insects that defaecated, the blood meal size was correlated with the time to first dejection in females $(\mathrm{r}=-0.64, \mathrm{n}=$ $35, \mathrm{p}<0.005)$ and nymphs $(\mathrm{r}=-0.64, \mathrm{n}=45$, $\mathrm{p}<0.005)$. These relationships were significant

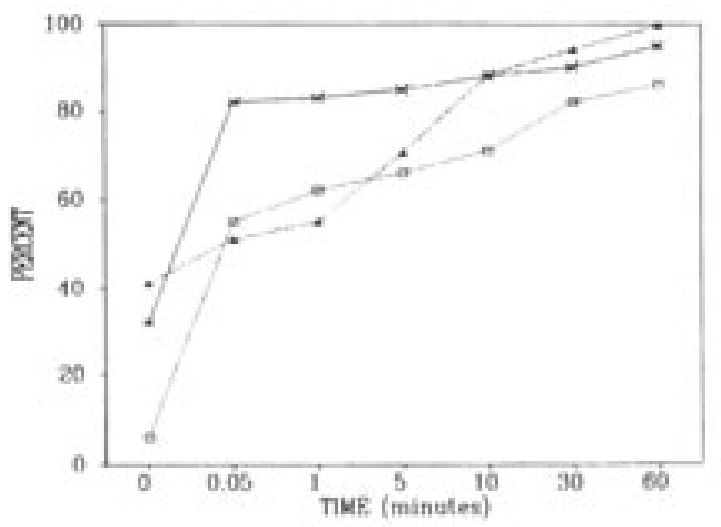

Fig. 4: accumulated percentage of insects which defaecated during feeding (time 0 ) and at different times afterwards nymphs ( ) females (X) males ( $\square$ )

(multiplicative model) and allow us to deduce that females must ingest more than $80 \mathrm{mg}$ of blood and nymphs must ingest more than $60 \mathrm{mg}$ in order to promote defaecation during feeding (Fig. 5).

The number and volume of the defaecations emitted during and immediately after the feeding also depends on the amount of ingested blood in females and fifth instar nymphs. In males, a significant relationship was not found.

\section{DISCUSSION}

The results obtained demonstrate that in $T$. sordida the blood meal size controls the excretion behaviour in the following way: (1) defaecation time is negatively correlated with the blood meal size; (2) the volume of emitted faeces is directly related to the blood meal size, and (3) the frequency of the emissions is also directly related to the blood meal size. The dependence of defaecation time on the quantity of blood ingested was also observed for T. infestans (Trumper \& Gorla 1991) and $R$. prolixus (Kirk \& Schofield 1987). The relation- 
TABLE III

Feeding and defaecation behaviour of Triatoma sordida and Triatoma infestans

\begin{tabular}{|c|c|c|c|c|c|c|c|c|c|}
\hline \multirow[t]{2}{*}{ Species } & \multicolumn{3}{|c|}{$\mathrm{RMS}^{a}$} & \multicolumn{3}{|c|}{$\%$ insects $^{b}$} & \multicolumn{3}{|c|}{ index ${ }^{c}$} \\
\hline & $\mathrm{N}$ & $\mathrm{FF}$ & MM & $\mathrm{N}$ & $\mathrm{FF}$ & MM & $\mathrm{N}$ & FF & MM \\
\hline T. infestans & $3,3^{d}$ & $1,1^{d}$ & $1,2^{d}$ & $3,3^{e}$ & $0^{e}$ & $0^{e}$ & $1,2^{e}$ & $1,0^{e}$ & $0,9^{e}$ \\
\hline T. sordida & 4,1 & 1,3 & 0,9 & 41 & 88 & 71 & 1,0 & 1,9 & 0,7 \\
\hline
\end{tabular}

$a=$ RMS relative meal size; $b=\%$ of insects that defaecated during feeding; $c=$ defaecation index; $d=$ RMS were derived from Perlowagora (1973); $e=$ percentage of insects that defaecated during feeding and the index were derived from Zeledón et al. (1977).
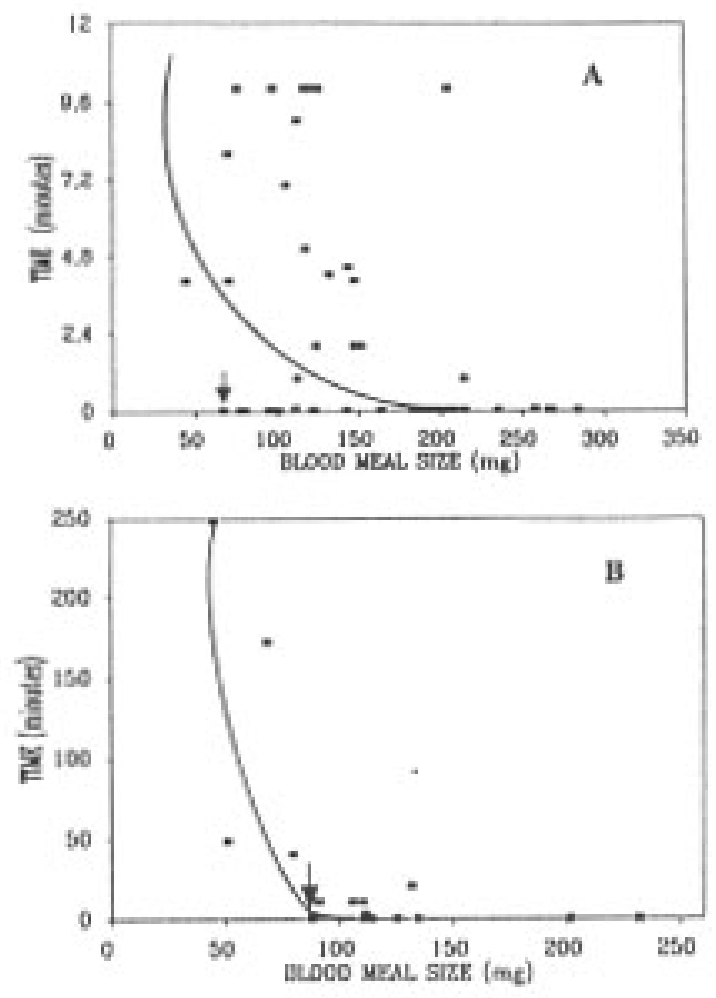

Fig. 5: relationship between time to first faecal drop and blood meal size in fifth instar nymphs (A) and females (B) of Triatoma sordida. Females $\mathrm{y}=34.10 \mathrm{x}^{-7.55}$; nymphs $=12.81$ $\mathrm{x}^{-2.95}$

ship between these two variables shows a similar slope in the three species. A minimum blood meal of $80 \mathrm{mg}$ was enough to produce defaecations during feeding on fifth instar nymphs of $T$. sordida, while nymphs of $T$. infestans that took the same quantity defecated $15 \mathrm{~min}$ after feeding (Trumper \& Gorla 1991).

The comparison of feeding and defaecation patterns observed here for $T$. sordida, and in $T$. infestans by other authors (Perlowagora 1973, Zeledón et al. 1977), shows that the females of $T$. sordida are the most efficient in terms of number of defaecations emitted (Defaecation Index, Table III).
The fifth instar nymphs of $T$. sordida had a greater relative meal size than $T$. infestans nymphs, ingesting up to four times the body weight. This is probably the reason for this species surviving more time under fasting conditions after a single meal (Perlowagora 1973, Juarez \& Castro 1982). Moreover, nymphs and adults of $T$. sordida not only defaecate immediately after feeding, they frequently emit defaecations during feeding.

This work demonstrates that in adults of $T$. sordida the size of the blood meal depends on the nutritional status of the insects at the moment of feeding. This dependence is important when it is related with active dispersal. Studies have demonstrated that a low nutritional status determines the dispersive flight of the adults (Schofield et al. 1991). This means that adults of $T$. sordida with a low body weight are the insects that would disperse and try to establish a new population. The results obtained here, suggest that these insects would take blood meals greater than $100 \mathrm{mg}$ and would emit dejections immediately after a feeding. Also, they would show an increased frequency and volume of emitted defaecations and would consequently lead to a higher T.cruzi transmission risk.

\section{ACKNOWLEDGMENT}

To the Servicio Nacional de Chagas for supply of insects and Diana Abal for Fig. 1 drawing.

\section{REFERENCES}

Carcavallo RV, Canale D, Martinez A 1988. Habitats de Triatomíneos argentinos y zonas ecológicas donde prevalecen. Chagas (Buenos Aires) 5: 8-17.

Forattini OP, Barata JMS, Ferreira Santos JL, Silveira AC 1982. Hábitos alimentares, infecção natural e distribução de Triatomíneos domiciliados na região Central do Brasil. Rev Saú Públ São Paulo 16: 171204.

Forattini OP, Ferreira OA, Rabello EX, Soares Barata JM, Ferreira Santos JL 1983. Aspectos ecológicos da tripanosomiase americana XVIII. Desenvolvimento e ciclos anuais de colonias de Triatoma infestans, Triatoma sordida e Rhodnius neglectus em ecotopos artificiais, no ambiente peri e extradomiciliar. Rev Saú Públ São Paulo 17: 243262. 
Forattini OP, Rabello OX, Ferreira OA, Rocha e Silva AEO, Ferreira Santos JL 1984. Aspectos ecológicos da tripanosomiase americana XXI. Comportamento de especies triatomineas silvestres na reinfestação do intra e peridomicílio. Rev Saú Públ São Paulo 18: $185-208$.

Freitas JLP, Siqueira AF, Ferreira OA 1960. Investigações epidemiológicas sobre triatomíneos de hábitos domésticos e silvestres com auxílio da reação de precipitina. Rev Inst Med Trop São Paulo 2: 90-99.

Juarez E, Castro Silva EP 1982. Comportamento do Triatoma sordida em condições de laboratório. Rev Saú Públ São Paulo 16: 1-36.

Kirk ML, Schofield CJ 1987. Density-dependent timing of defaecation by Rhodnius prolixus, and its implications for the transmission of Trypanosoma cruzi. Trans R Soc Trop Med Hyg 81: 348-349.

Perlowagora-Szumlewicz A 1973. Species and stage interaction in the feeding behaviour of vectors of Chagas' disease (The importance of determinants in planning for greater efficacy and standardization of xenodiagnostic procedure). Rev Inst Med Trop São Paulo 15: 139-150.

Schofield CJ, Lehane MJ, McEwan P, Catalá SS, Gorla D 1991. Dispersive flight by Triatoma sordida. Trans $R$ Soc Trop Med Hyg 85: 676-678.

Trumper EV, Gorla DE 1991. Density-dependent timing of defaecation by Triatoma infestans. Trans $R$ Soc Trop Med Hyg 85: 800-802.

WHO 1983. Integrated vector control. World Health Organization Technical report Series 688.

Zarate LG, Lopez GM, Ozuna MC, Garcia-Santiago G, Zarate RJ 1984. The biology and behavior of Triatoma barberi (Hemiptera: Reduviidae) in México IV: Feeding and defecation patterns. J Med Ent 21: 548-560.

Zeledon R, Alvarado R, Jiron LF 1977. Observation of the feeding and defaecation of three Triatominae species (Hemiptera, Reduviidae). Acta Trop 34: 6577. 
414 Feeding and Defaecation Patterns in T. sordida • LB Crocco, SS Catalá 